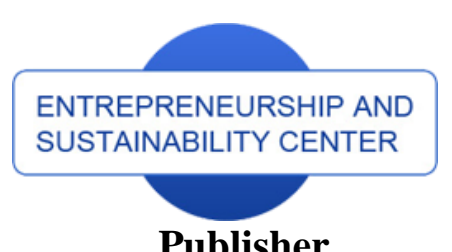

Publisher

http://jssidoi.org/esc/home
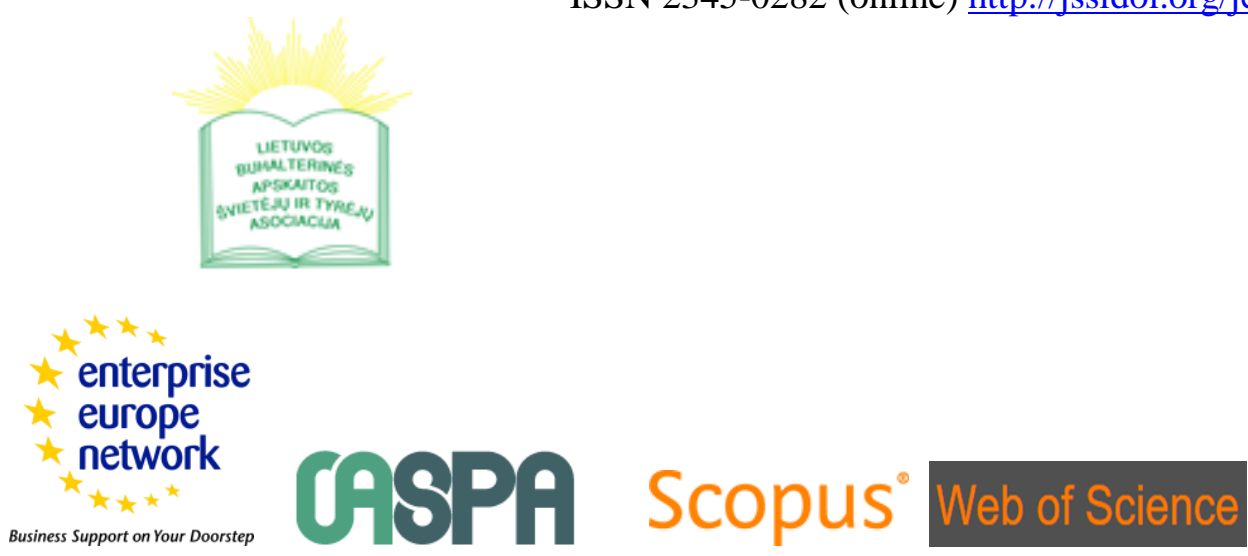

\title{
BEHAVIOR OF THE LITHUANIAN INVESTORS AT THE PERIOD OF ECONOMIC GROWTH
}

Egidijus Bikas ${ }^{1}$, Vitalija Saponaite் ${ }^{2}$

${ }^{1,2}$ Vilnius University, Faculty of Economics and Business administration, Sauletekio 9 LT-10223, Vilnius, Lithuania

E-mails: ${ }^{1}$ egidijusvln@gmail.com,${ }^{2}$ v.saponn@gmail.com

Received 19 March 2018; accepted 5 May 2018; published 30 September 2018

\begin{abstract}
Modern scientists speak and write about investor's psychological factors, decision-making processes, and the importance of financial behavior in the investment process. One of the modern theories - an efficient market - focused on rational investors. According to it, investors rationally manage their investment portfolio; rationally respond to constantly changing information and make rational changes to newly acquired information. However, the prospect theory has proven that irrational investor decisions play an important role in the investment process. An assessment of irrationality of investors is important for governments, fund managers and investors, eventually for all participants of financial market. For some, this is an opportunity to additional funds, to receive higher income, for others, would provide the added value, as they could identify themselves as investors. Understanding how decisions are influenced by behavior it is important both for self-education and investment decision-making. The article aims to identify the typology of the Lithuanian investors by distinguishing behavioral deviations that influence the behavior of investors' decisions in the stage of the country's economic growth. The research will identify types of physical entities, behavioral deviations, motives of investment decisions made. The qualitative and quantitative methods are used to perform the research: investor inquiry, correlation and regression analysis.
\end{abstract}

Keywords: behavior finance; behavioral deviations; investment decisions

Reference to this paper should be made as follows: Bikas, E.; Saponaite, V. 2018. Behavior of the Lithuanian investors at the period of economic growth, Entrepreneurship and Sustainability Issues 6(1): 44-59. http://doi.org/10.9770/jesi.2018.6.1(4)

JEL Classifications: D9, D14, E71

\section{Introduction}

Scientists now speak and write about the psychological factors of investors, the decision-making processes, and the importance of financial behavior. In the past, the importance of psychology in investment processes was not 
separate because it was considered that society was rational, rational at decision-making and interpreted the information and knowledge that was rightly understood.

The idea of effective market theory, which has been studied, speaks of rational investors who rationally manage their investment portfolio, rationally respond to ever-changing information and make rational changes to newlyreceived information. They do not focus on short-term deviations that are not attributable to rational actions. Effective market theory also speaks of irrational investors, but, according to the theory, they do not make a big impact on the market, because their actions are non-permanent, and, therefore, do not distort the market. Basic economic theories (Absolute income, permanent income and life cycle theory) are also oriented towards rational investors, but these theories already mention the psychological factors, that influence the behavior of people. Financial behavior begins when the scientists begin to speak not only about rationality, but also about the influence of internal and external factors on decision making.

The assessment of investor behavior when making investment decisions are important for the government, investment fund managers, other financial market participants and investors themselves (Jelnova, 2013). The government is relevant on budget debts that arise every year, so it is necessary to raise additional funds for debt reduction. The government takes into account the standard behavioral deviations of investors, can focus on them and offer attractive bonds to investors (Ozerchuk, 2014).

For fund managers it is important to identify common types of investors and their characteristics that encourage them to make certain investment decisions. The fund manager, having identified the characteristics and type of investors, can, depending on investor's deviations and behavioral patterns, create attractive portfolios for investors according to their types. In this way, there is a motivation in investing, which in the past was unattractive due to certain emotional barriers or behavioral deviations.

Meanwhile, determining the behavioral typology it would give the investor the appropriate added value, because he could identify himself as an investor. Understanding how actions are influenced by behavior it is important both for self-help and investment decision-making. Having identified irrational deviations, an investor can identify them and draw attention to them when making decisions. Also, aware of his behavioral deviations, he can choose the right investment instrument.

An investor-type and behavioral deviation study was conducted three years after the peak of the financial crisis, then repeated three years later, i.e. 2010 and 2013. It was decided to repeat this study three years later (2016) in the context of economic recovery, in order to analyze investor behavior. Has the economic recovery affected the behavior of investors, have they become more rational, or maybe investors have forgotten the price of possible negligence and became less prudent and take irrational decisions?

The aim of the paper is to identify the types of the Lithuanian investors dominating in Lithuania, whose behavioral deviations influence the behavior of investors in Lithuania after the financial crisis, while making investment decisions. The qualitative and quantitative methods are used to perform the research: investor inquiry, correlation and regression analysis.

\section{Financial behaviour design}

The modern financial market is affected by many factors: the abundance of information, accessibility, economic processes, political and legal constraints, and so on. However, the greatest influence is made by people's reaction to certain situations, events that were or are now taking place, and the perception of the situation itself. Every investor constantly makes personal decisions, no matter what financial instruments he or she operates. All 
investors, starting with beginners and ending with experts, have to answer many questions: what kind of financial instruments to buy what risks to take, how diversify the portfolio, etc. Investors know and use modern portfolio theory, create efficient portfolios, use statistical data analyze that help them to select a specific financial instrument. In other words, investors are already thinking of rational market participants and base their decisions on calculations: probability theory, statistics and financial mathematics. However, the researchers argue that the decisions made by investors are strongly influenced by psychological stimuli that are associated with financial behavior. Financial behavior is a combination of finance and psychology. This is a science that analyzes market situations in which active participants are showing limited rationality and complicity (Bikas, 2010). Financial behavior is based on empirical human-social and emotional research to understand the financial decisions made by the investor. According to Shefrin (2001), financial behavior is the science of the impact of psychology on financial markets and the decision-making process. Psychology deals with behavioral processes, and how these processes affect human actions that differe from traditional economic assumptions. The variety of financial behavior definitions is very wide. The authors emphasize the novelty of the theory of financial behavior, which derives from classical financial theories, paying attention to the changes in society. Classical financial theories are complemented by new - psychological factors that encourage investors to make one or the other decision (Table 1).

Table 1. A variety of financial behavior definitions

\begin{tabular}{|c|c|c|}
\hline Author & Year & Definition \\
\hline Goldberg et.al. & 1999 & $\begin{array}{l}\text { Behavior-oriented financial market theory: a discipline based on the fact that people } \\
\text { are only rational to a certain extent. }\end{array}$ \\
\hline Fuller. & 2000 & $\begin{array}{l}\text { The financial behavior seeks to explain the regularities of investors' thinking } \\
\text { processes, as well as the emotional processes involved and the extent to which they } \\
\text { influence decision-making. }\end{array}$ \\
\hline Fromet & 2001 & $\begin{array}{l}\text { Financial behavior examines how investors collect, submit information when making } \\
\text { investment decisions. }\end{array}$ \\
\hline Ritter & 2002 & $\begin{array}{l}\text { Financial behavior seek to supplement the standard financial theories - incorporating } \\
\text { psychological aspects into the decision-making process. }\end{array}$ \\
\hline Levy et.al. & 2005 & Theories that can explain market inefficiencies and market anomalies. \\
\hline Bodie et.al. & 2007 & $\begin{array}{l}\text { Financial market models that highlight the impact of potential psychological factors on } \\
\text { investor behavior. }\end{array}$ \\
\hline Jordan, Miller & 2008 & $\begin{array}{l}\text { A financial area that analyzes investor thinking about the decision acceptance and } \\
\text { market prices. }\end{array}$ \\
\hline Gitman & 2008 & $\begin{array}{l}\text { Research that explains the role played by emotions and other subjective factors in } \\
\text { making investment decisions. }\end{array}$ \\
\hline Lovric et.al. & 2008 & $\begin{array}{l}\text { Financial behavior is a finance sub discipline that uses cognition and social psychology } \\
\text { insights to the knowledge of how investors make financial decisions. }\end{array}$ \\
\hline Thaler et.al. & 2009 & $\begin{array}{l}\text { Integration of classical economics and financial theory with psychology and decision- } \\
\text { making in exploratory sciences. }\end{array}$ \\
\hline
\end{tabular}

Scientists have different definitions of financial behavior, but everyone talks about the irrationality of a person and the importance of his decision making, about distortions in the market, and the anomalies that arise when irrational decisions are made. The presented financial behavioral attitudes form the premise that decisions depend on people's personal qualities, individuality, emotional state, etc. Understanding the behavior of investors begins with knowing the factors. It is recognized that economic behavior is not limited to qualitative market events and quantitative data analysis, but also reflects the perception, understanding and evaluation of events and data of economic entities, while emphasizing the importance of subjectivity in making financial decisions (Mentel et al. 206; Michailova et al. 2017; Sinem et al. 2017; Ohotina et al. 2018; Kunitsyna et al. 2018). D. Kahneman and A. Tversky (1981) first proved that the behavior of irrational investors is the consequence of understanding and processing incorrect information and proving how errors of reasoning emerge and become firmly established in our tinking. Recently, the focus of research on investor behavior and its impact on investment performance has 
continued to grow, with particular attention being paid to identifying and rating investor typologies. The approach to risk and uncertainty is significantly affected by financial behavior and investor types. According to Aleknevičienè (2004), investors' attitude to risk and uncertainty is uneven. Some investors tend to risk more, others less. Depending on the risks, the following investor types are distinguished:

- $\quad$ Conservative - assumes a low level of risk, invests in shares and bonds of large and stable issuers. This type of investor strives for maximum confidence in the expected results of portfolio.

- $\quad$ Modest - assumes a moderate level of risk, invests in shares and bonds of large and medium-sized issuers. This type of investor assumes lower reliability for the expected results of its portfolio, in order to obtain higher profitability compared to Conservative type investor.

- $\quad$ Aggressive - assumes a high level of risk, invests in randomly selected issuer's shares. This type of investor is looking for the highest profitability from the formed portfolio.

Jerry Robinson (1999) expands the investor classification, distinguishing:

- $\quad$ Avoiders - the most careful, hoping for the worst case and often loses, because without risk, he loses great opportunities on the market.

- The headaches is avoiders opposite and often risks too much. He ignores the facts, does not look at the risk, and very often fail because he is not careful.

- Adventure lover - enjoys the risk that is challenging and enjoyable for him. He is looking for opportunities to take risks, but he does not do it blindly and has certain limits. Most often, these are market speculators.

- The calculator - understands that in order to go forward, you need to take advantage of the opportunities, but each of them is on his own risk. Before deciding, this investor strives to gather as much information as possible, to evaluate what the result are and how to reduce the risk.

- A conservative investor can be compared to a avoiders type investor, a modest investor with a calculator, an aggressive investor type, respectively, a headache or an adventurer. Meanwhile, Pompian (2010) divided three investor personality dimensions:

1. $\quad$ Idealist (I) versus Pragmatist (P)

2. $\quad$ Framer $(\mathrm{F})$ versus Integrator $(\mathrm{N})$

3. Reflector (T) versus Realist (R)

On the other hand, Pompian has identified 8 investor personality types based on decisions made and their deviations (Fig.1.).

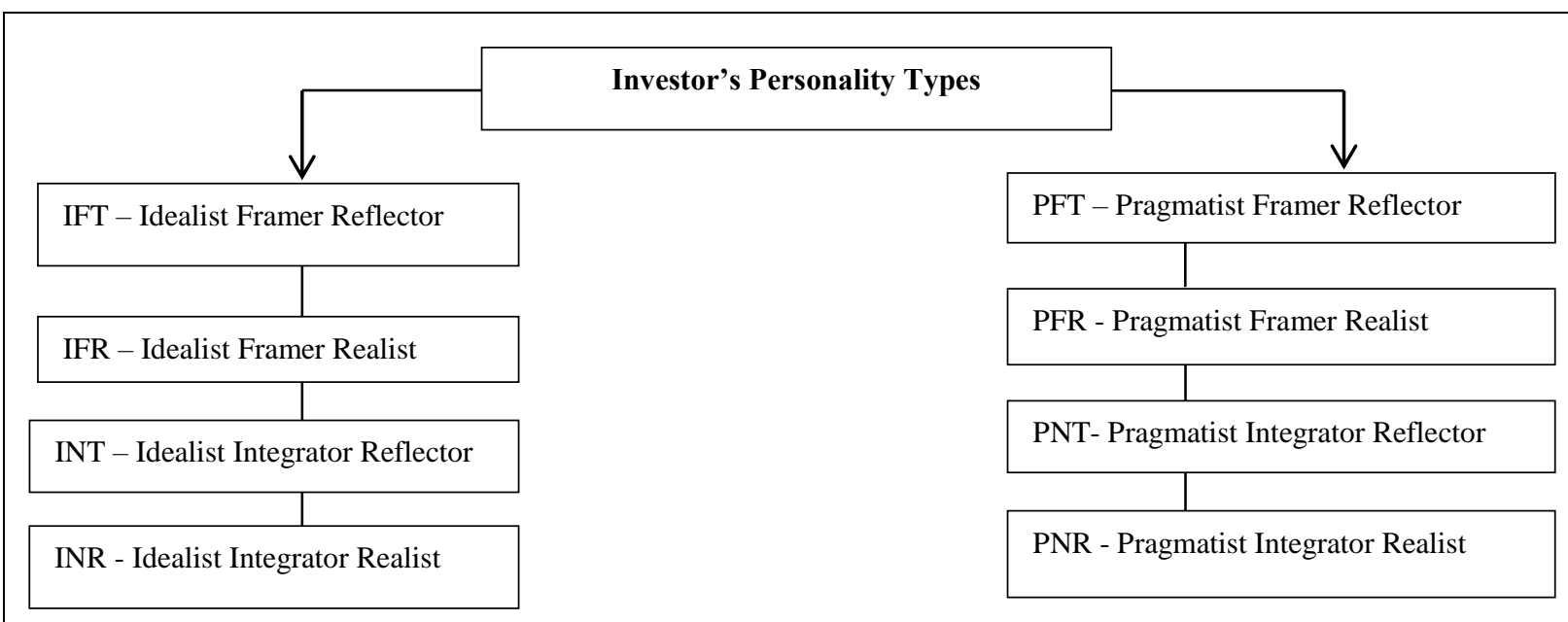

Figure 1. Investor's personality types (Source: Pompian, 2010) 
According to Pompian in market, the following investors are active: The Idealist (I) overestimates the investment capability, reveals too optimistic capital markets and does not seek additional information that contradicts his convictions. He believes that better than average perceptiveness and intelligence gives him better control. These investors do not perform detailed analyses. Such investors demonstrate excessive self-confidence, an illusion of control, newness, representation, optimism, and self-tie-in.

The pragmatist $(\mathrm{P})$ demonstrates real perceptions of their possibilities and limitations. This type of investor trusts the capital market and has a healthy scepticism in terms of his knowledge. He understands that investment activity is probabilistic, and carries out a detailed analysis of the market. Normally, it does not show a deviation from rational behavior.

The framer (F) demonstrates trends, attachment to certain events or situations, does not look at how a particular investment looks in a common investment portfolio. There is no flexibility in analyzing problems, not thinking about various external stimuli that could affect the overall portfolio due to some reckless investment. He usually demonstrates standing/anchor, conservatism, mental accounts, avoiding uncertainty, framing.

An integrator $(\mathrm{N})$ is able to examine the wider context and external information. He sets up his investment portfolio as a whole, composed of different particles that are interdependent. Investor understands that the investments correlate, and depending on that, they form their own investment portfolio. Flexibly takes into account the market and prices of financial instruments. These investors do not show the deviations of the frames.

The Reflector $(\mathrm{T})$ is afraid to assume responsibility because he does not seeks to live with the results of his decisions. He justifies and reasonably interprets the reasons for his mistakes, accepts no responsibility. Demonstrates these deviations: cognitive dissonance, self-control, exposure, avoidance of loss, avoidance of regret, factual situation, supposed prediction.

Realist (R) assumes all responsibility for his actions. He does not feel sorry for it, so it's easy to make decisions in difficult circumstances. The investor does not show the deviations that are indicated by the reflectors.

In addition, the author distinguished emotional and cognitive deviations that cannot be related to rational behavior in making investment decisions, as all the investors have these abnormalities (Table 2, Table 3).

Table 2. Emotional deviations

\begin{tabular}{|c|c|}
\hline Sphere & Explanation \\
\hline Endowment & Individuals value specific assets more when they have the right to dispose of them. \\
\hline Self-control & Human consumes today what he will consume tomorrow. \\
\hline Lossaversion & A situation where a person feels a stronger impulse to avoid loss than to earn profit. \\
\hline $\begin{array}{l}\text { Regret } \\
\text { aversion }\end{array}$ & The person does not take decisive action because he fears that any decision will still be inadequate. \\
\hline Status Quo & $\begin{array}{l}\text { Prepare a person with a range of decision options to choose any solution that confirms the existing status quo instead of } \\
\text { other alternatives that bring about changes. }\end{array}$ \\
\hline
\end{tabular}

(Source: Pompian, 2010) 
Emotional deviations describe the behavior of an investor, which occur through the loss of an asset, the possible occurrence of a loss, or the misunderstanding of his own decision. Emotional deviations are such as when an investor realizes that he himself is responsible for the rebound of an action.

Table 3. Cognitive deviations

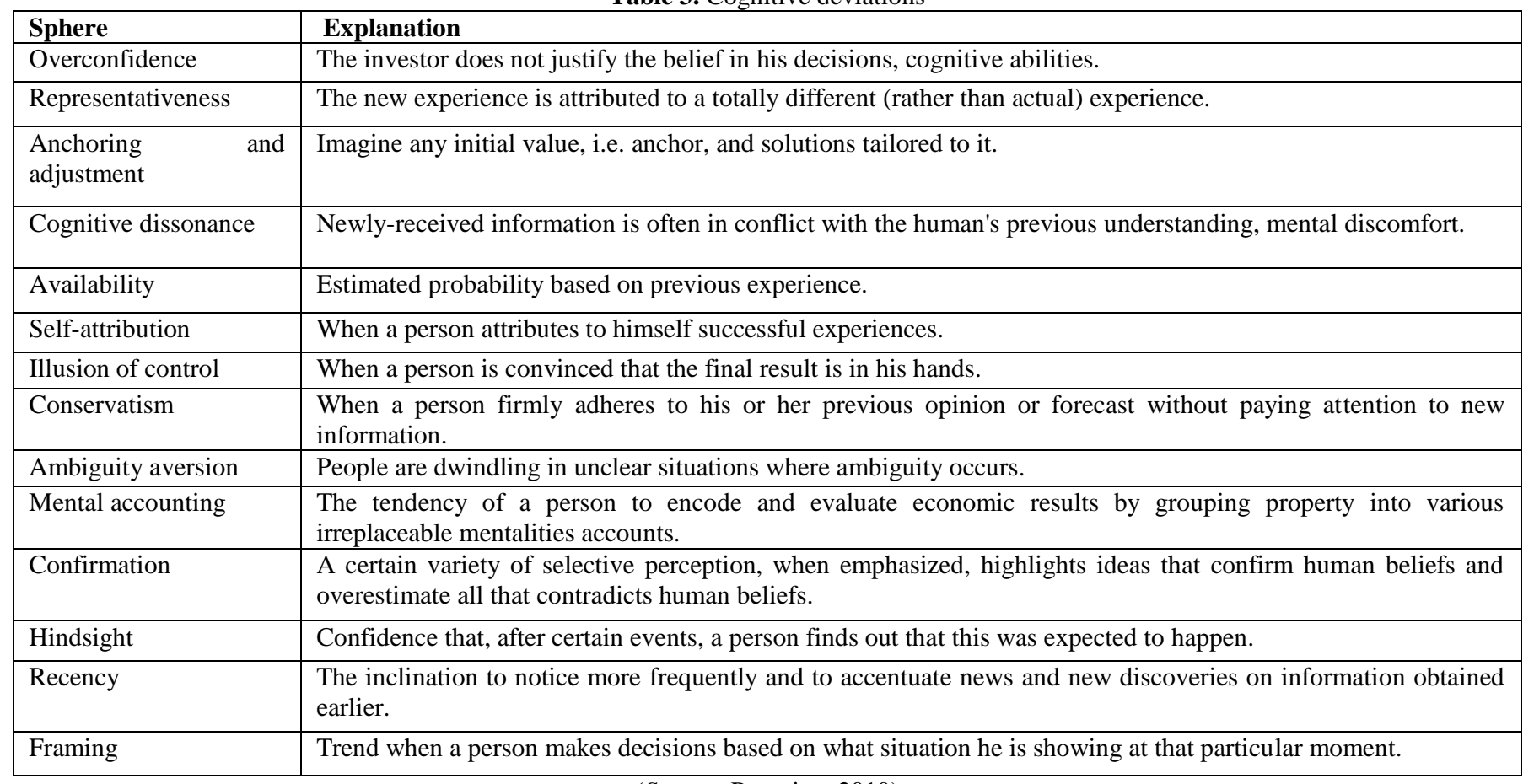

(Source: Pompian, 2010)

Meanwhile, detailed cognitive deviations indicate the influence of decisions on personal decisions. All cognitive deviations are irrational, legitimate actions of the investor, show the fear of novelty, and draw attention to the tendency not to take responsibility, instead to accuse the environment, inaccuracy of information, another person, but not himself.

\section{Lithuanian investor inspection methodology}

The purpose of the survey is to identify and assess the types of investors in a stable economic, political situation in the country, i.e. 2016 and the obtained results compared with previous studies of this type in assessing changes. Research method - an investor survey. The Pompian (2010) investor-type model was used to interpret the research and the results. Using this model, it is possible to accurately identify the types of investors based on people's actions and patterns of thinking and their deviations.

The research is conducted on the Internet site, on the social page www.manoapklausa.lt, in order to attract the largest possible number of inhabitants of different cities in Lithuania. The aim is to make the questionnaire as objective as possible, without any influence on the respondents.

The research sample is persons living in the territory of the Republic of Lithuania who are over 20 years and who will be selected on the basis of quota selection. According to the data of the Department of Statistics, at the 
beginning of 2015, 2,325,402 people over the age of 20 lived on the territory of the Republic of Lithuania. Due to this large number of people, the sampling method was chosen to determine the sample size of a whole:

$$
\mathbf{n}=\frac{\mathbf{z}^{2} * \mathbf{p}(1-\mathbf{p})}{\mathbf{e}^{2}}
$$

Where: $\mathrm{n}$ - required sample size; $\mathrm{z}$ - Standard Error Size Units in Normal Distribution, which will meet the desired degree of reliability; $p$ is the proportion of the whole that corresponds to the prevailing characteristics; e sampling error.

In this case, the confidence level (z) $95 \%$ is chosen, for this degree of reliability at $\mathrm{z}=1,96$, the ratio of the total (p) to 0,5 , i. e. the pessimistic option is chosen, with only half of respondents show prevailing characteristics and a selection error (e) of $6 \%$. Therefore:

$$
266=\frac{1.96^{2} * 0.5(1-0.5)}{0.06^{2}} .
$$

To perform this research, 266 people were interviewed for the results to be representative. To determine the behavior: deviation, behavior and type of the Lithuanian investors, the Pompian (2010) methodology is used. According to this method, a questionnaire was created to help to identify the type of investor behavior, the deviations inherent in a certain type.

The questionnaire consists of 3 parts:

- Identification of the respondent. Identification of respondent's gender, age, education, activity, monthly average income and managed assets.

- Saving, investing. Identify whether respondents are saving on motives that encourage them to save money, how much they save per year, and whether they are financially investing.

- Behavioral determination. Determine the respondents' behavior type. This section is intended only for the investing respondents identified in the second part of the questionnaire. According to the answers selected in the survey, the respondent is assigned as a type specific to the answer variant. Analyzing each respondent, he is assigned as a certain type of Pompian investor's personality.

Results are compared with two performed studies: E. Bikas, A. Kavaliauskas, 2010 and E. Bikas, D. Jurevičienè, L. Novickytė, G. Keliuonytė-Steniulienė and P. Dubinskas in 2013 (Bikas et al. 2013).

\section{Research results}

Empirical research was made in January - May 2016. The survey interviewed 306 respondents. The survey was attended by 102 men and 204 women. The largest monthly income of respondents ranges from 435 EUR to 869 EUR, representing $40 \%$ of all respondents' choices. $22 \%$ of respondents receive up to 1304 EUR per month. One fifth of the respondents receive higher income than 1,304 EUR and the remaining $16 \%$ receive up to 435 EUR per month, three quarters of respondents are educated and have university education, $16 \%$ of respondents have college education. $66 \%$ of respondents are employees, $14 \%$ of respondents have their own businesses, $7 \%$ are state employees, and the remaining $13 \%$ are unemployed. Empirical research results showed that $72 \%$ of respondents save, $52 \%$ of household make budgets and almost all respondents who have a household budget have a financial plan. Positive replies to this question made 50\% of respondents. During the survey, one third of the 
The International Journal

ENTREPRENEURSHIP AND SUSTAINABILITY ISSUES

ISSN 2345-0282 (online) http://jssidoi.org/jesi/ 2018 Volume 6 Number 1 (September) http://doi.org/10.9770/jesi.2018.6.1(4)

respondents respond that they make financial investments and participate in a further study on investors' financial behavior and investor type.

Only those questionnaires that indicated that the respondent was investing was involved in the study. The vast majority of respondents manage the tangible and financial assets of 2900 EUR - 14480 EUR. $33 \%$ of respondents manage assets ranging from 14481 EUR to 57924 EUR. $12 \%$ of respondents manage assets of higher value.

Analyzing the results of the survey, it was found out that the majority of respondents are characterized as the idealist - framer/integrator-realist. Their distribution by gender is almost the same: men with this type are 27 units and women are 28 units. According to the Pompian theory, people of this type are mostly characterized by deviations in idealistic behavior, which have excessive self-confidence, an illusion of control, novelty, representation, optimism, and self-confinement. Sometimes there are also fringe deviations that demonstrate standing / anchor, conservatism, mental accounts, avoiding uncertainty, framing. These deviations are often obscured by the type of the integrator, which is inverse to the type of framer. People of this type do not show the reflector's deviations, because according to the survey results, respondents demonstrate the character of a realist type. The pragmatist-framer-realist type was only male, no female was identified by the type mentioned above. A type that is characterized by all possible behavioral deviations is an idealist-framer-reflector -for the most part, this type of investor is characterized by women (Fig.2).

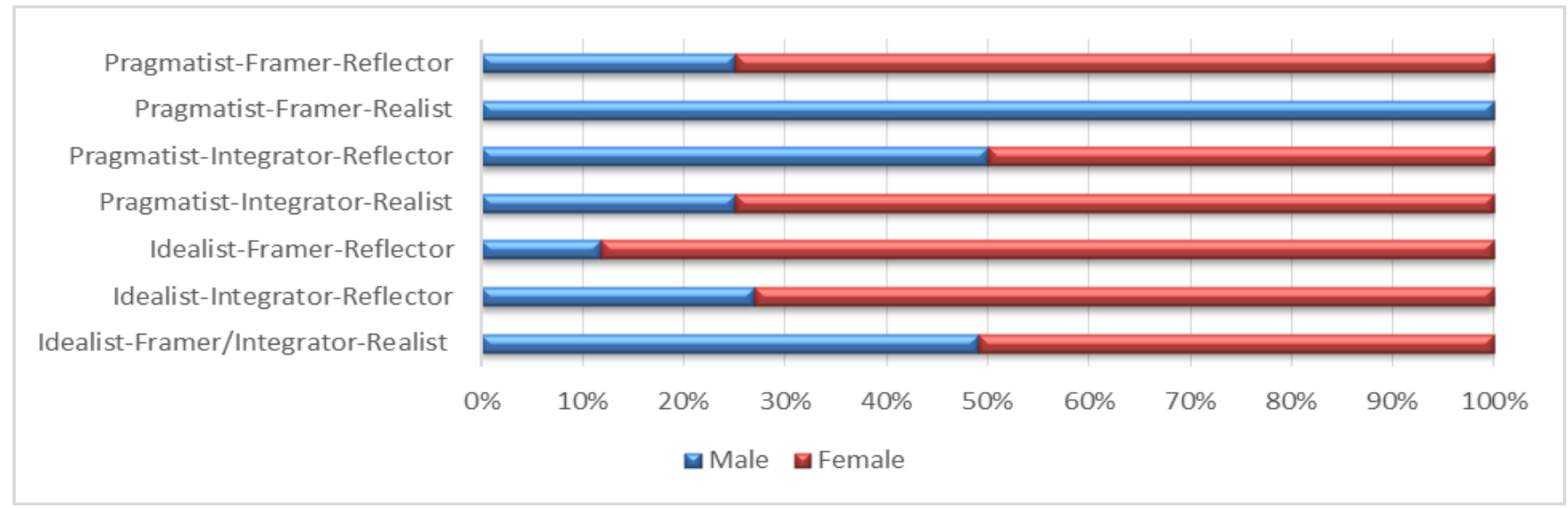

Figure 2. Distribution of respondent types by gender (Source: created by the authors)

By analyzing types by age, it is noticeable that the features of idealist-integrator/framer-realist are characteristic to all age groups (except for respondents in the 60 - 69 age group). This type of respondents is mostly in the age group of $20-29$, but these types of deviations are also characterized by respondents aged $40-49$. The respondents who are characterized by all possible deviations in behavior are idealistic-framer-reflector. According to research results, all this type of deviations are characterized by the respondents which are 20 - 39 and 50 - 59 years old. Strangely enough, a type that does not show any behavioral deviations (pragmatist-integrator-realist) is characteristic of only two age groups, i.e. 20 - 29 years old and 60 - 69 years old respondents. Respondents aged 20 - 29 are visible in all types, with the exception of pragmatist-framer-realist. The respondents of this type are only standing/anchor, conservatism, mental accounts, avoiding uncertainty, framing. Pragmatist-framer-realist type has respondents of 50-59 years (Fig.3). 


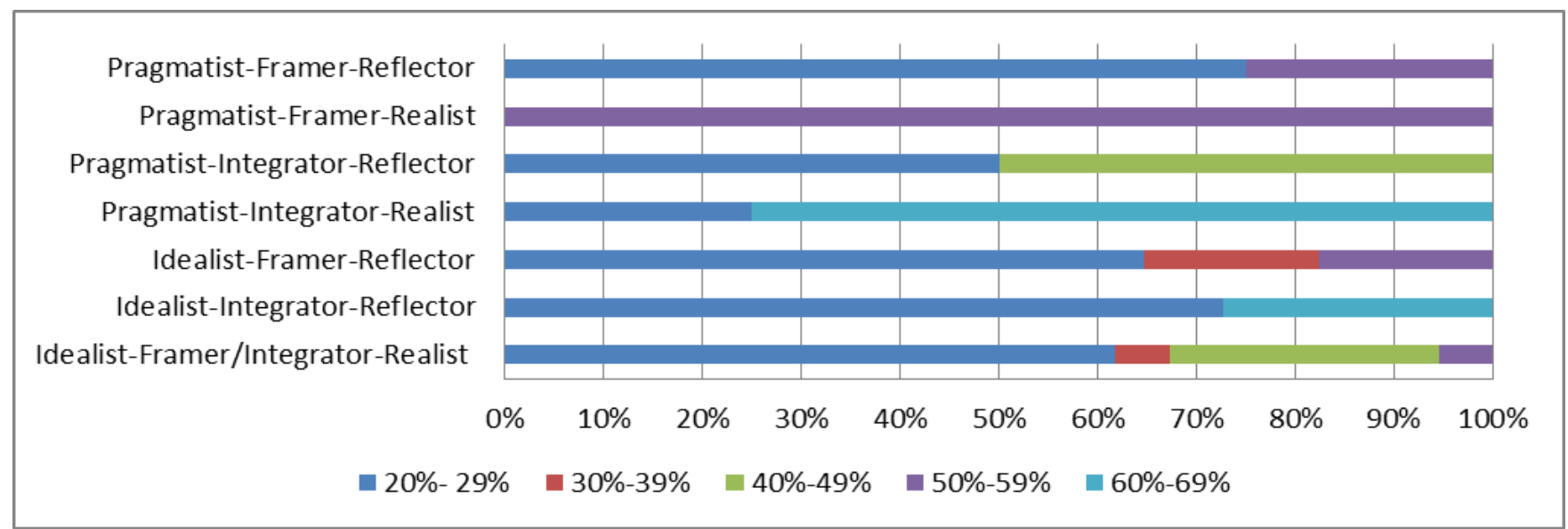

Figure 3. Distribution of respondent types of behavior by age (Source: created by the authors.)

The monthly income received by respondents does not have a significant impact on the investor type. Respondents who do not have any behavioral deviations (pragmatist-integrator-realist), according to the survey, receive 870 EUR - 1304 EUR per month. Respondents with all possible behavioral deviations (idealist-framerreflector) do not differ in income, they are distributed through all possible income groups. The respondents with the highest monthly income for pragmatist-framer-realist are men between 50 and 59 years of age (Fig. 4.).

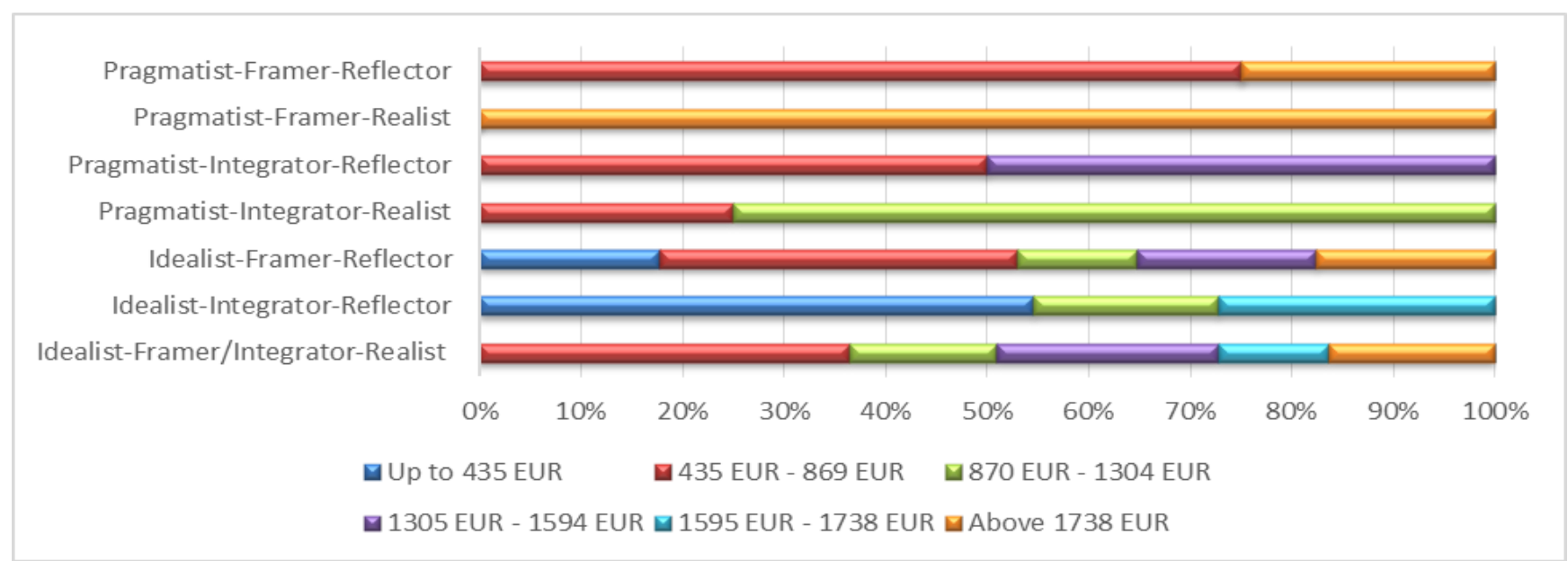

Figure 4. Distribution of respondent types of behavior by monthly income (Source: created by the authors)

The distribution of respondents by employment is depicted in Fig. 5. Hired workers are mostly distinguished by the types of pragmatist-integrator-realist and idealist-integrator-reflector. Also, employed workers are the only ones who are completely devoid of behavioral deviations - this is the type of pragmatist-integrator-realist. State employees are distributed in almost all types of investors, but they are the only ones that are characterized by pragmatist-framer-realist type deviations. The unemployed are distinguished by the deviations of the idealistframer-reflector, which means that they have all deviations of behavior. The owners of the company are characterized by the idealist-framer/integrator-realist and pragmatist-integrator-reflector types. Young people were divided into only the idealist-framer/integrator-realist type (Fig. 5.). 


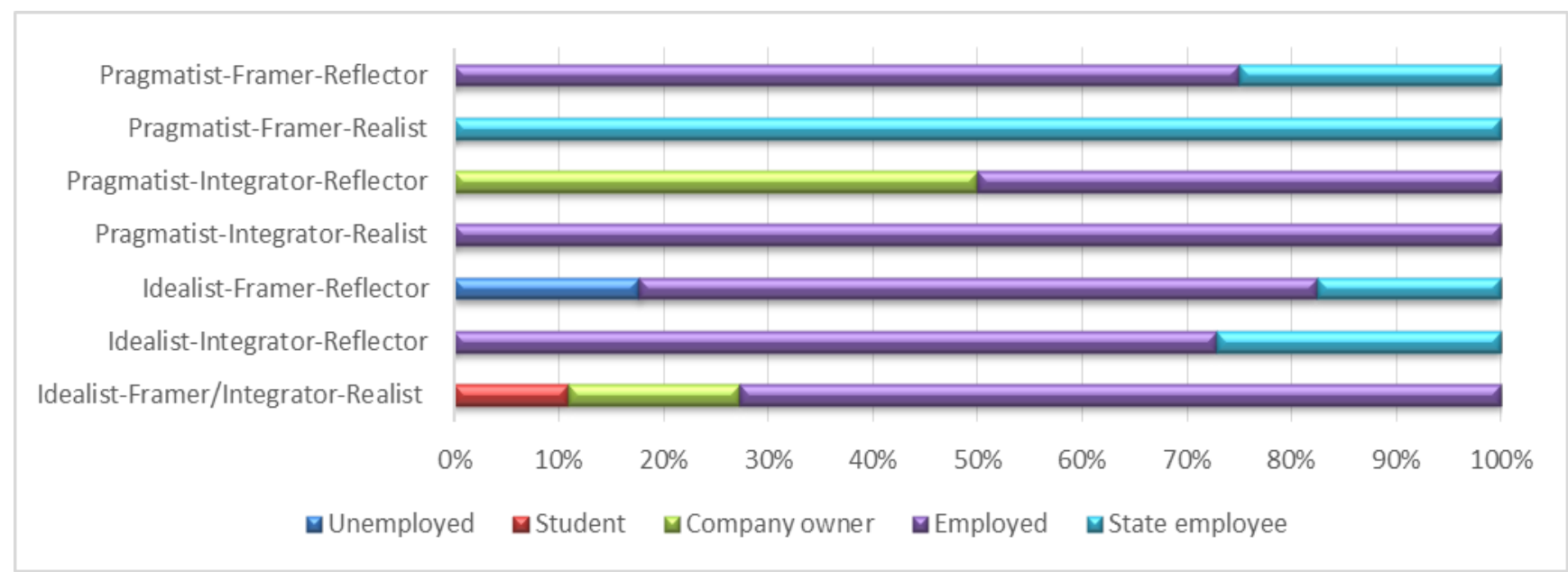

Figure 5. Distribution of respondent types of behavior by employment (Source: created by the authors)

Education does not affect the type of investor (Fig. 6.). Respondents with university education are distributed according to all types of investors. Respondents with basic, secondary and college education are only in the most common type, i.e. y idealist-framer/integrator-realist. A type that has all the possible deviations (idealist-framerreflector) can only be people with basic education. Meanwhile, respondents with secondary education are also demonstrating non-deviating types (pragmatist-integrator-realist) compared with those with university education.

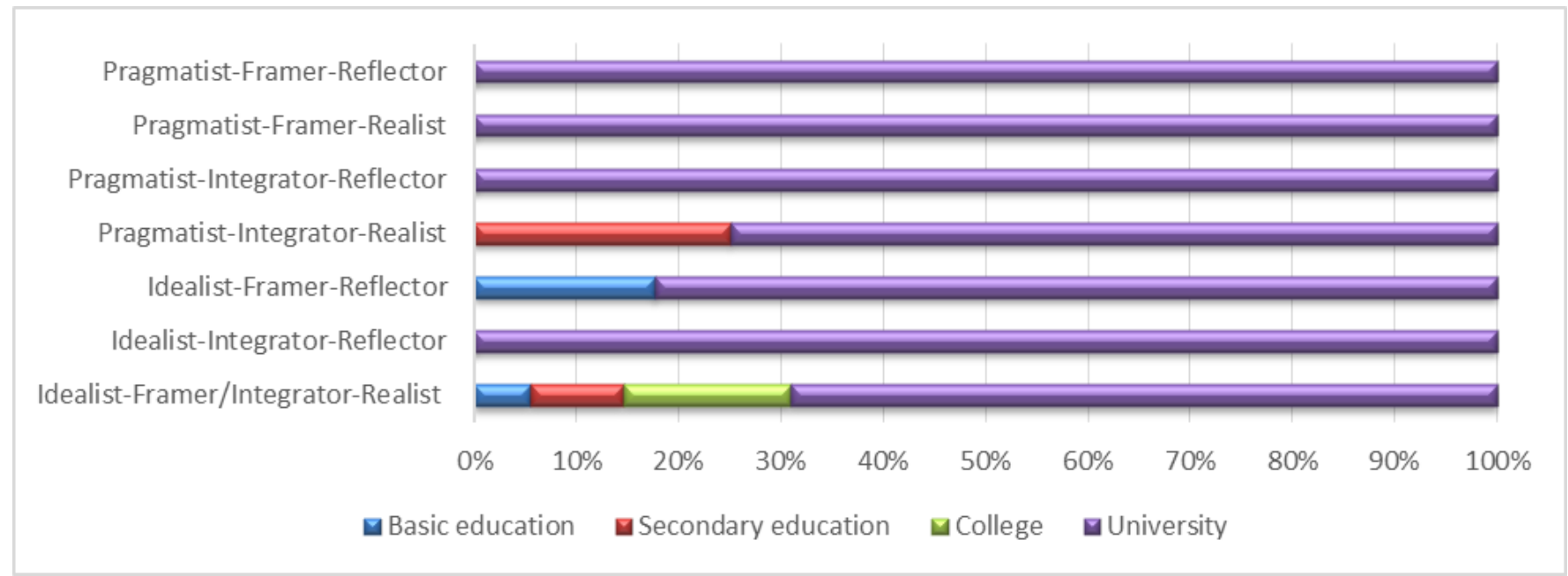

Figure 6. Distribution of respondent types of behavior by education (Source: created by the authors)

The types of the Lithuanian investors were identified (Table 4). The red line allocates respondents to rational and irrational investors and with certain behavioral deviations. On the left side of the red line are respondents with two or three signs of irrational investor type, and to the right of the red line are respondents with two or three rational investor type attributes. As it can be seen from the results obtained in Table 4, more than $40 \%$ (i.e., $45.45 \%$ ) of the Lithuanian investors are rational, only partially surrendering to emotions. They demonstrate the rational behavior of the irrational behavior of impurities (the good qualities of these investors reflect two or three of the rational investor type attributes). These types of investors are characterized by realistic possibilities, pragmatism, broad perspective, activity, sometimes pessimism and self-accusation. Empirical research has shown that $4.04 \%$ 
The International Journal

ENTREPRENEURSHIP AND SUSTAINABILITY ISSUES

ISSN 2345-0282 (online) http://jssidoi.org/jesi/ 2018 Volume 6 Number 1 (September) http://doi.org/10.9770/jesi.2018.6.1(4)

of Lithuanian investors' behavior is completely unrelated to irrational behavior, they are completely rational investors who do not show any behavioral deviations. Fully irrational investors (those with deviations from rational behavior) account for $17.17 \%$, and the total number of irrational investors (whose bad investor characteristics are reflected by two or three characteristics of an irrational investor type) is $54.54 \%$. These respondents are characterized by overestimation of opportunities, illusion of control, conservatism, inspiration, avoidance of loss, over-optimism, narrow-mindedness, passivity and accusation of circumstances.

Table 4. Distribution of Lithuanian investors by types (\%). (Source: created by the authors)

\begin{tabular}{|c|l|l|l|}
\hline \multicolumn{2}{|l|}{$\begin{array}{l}\text { Overestimation of opportunities, Excessive optimism, Narrow } \\
\text { attitude, Passivity, Circumventive conviction }\end{array}$} & $\begin{array}{l}\text { Realistic assessment of opportunities, Pragmatism, Pessimism, } \\
\text { Wide approach, Activity, Self-accusation }\end{array}$ \\
\hline & $\begin{array}{l}\text { Idealist-Framer-Realist; Idealist- } \\
\text { Integrator-Reflector; Pragmatist-Framer- } \\
\text { Reflector }\end{array}$ & $\begin{array}{l}\text { Pragmatist-Integrator-Reflector; Pragmatist- } \\
\text { Framer-Realist; Idealist-Integrator-Realist } \\
\begin{array}{l}\text { Framer- } \\
\text { Reflector }\end{array}\end{array}$ & $\begin{array}{c}\text { Pragmatist- } \\
\text { Integrator- } \\
\text { Realist }\end{array}$ \\
\hline 17,17 & 37,37 & 41,41 & 4,04 \\
\hline
\end{tabular}

Analyzing the Lithuanian investor profile, the results of the respondents were combined according to the types of investors and deviations from rational decisions (Fig. 7.). It turned out, which part of the Lithuanian investors have specific deviations from rational decision making, and what are those deviations. $50 \%$ of respondents have deviations in idealist behavior. These respondents rely too much on their own strengths and decisions. It is also very optimistic about the future, following only the current information available and making decisions based on such information. It is also convinced that only their insights give the desired (positive) result. Imagine being able to control any situation, though this is not the case. Indirect investors are distributed around the framer and reflector deviations. $27 \%$ of the respondents noted the deviations of the framer's behavior. These investors come from the initial value and combine their decisions, and also firmly adhere to their existing regulations and do not change their opinions and behavior when they come to new, changing information. Some investors tend to estimate economic results by grouping assets into various irreplaceable ones, i.e. y mentally-minded accounts, which are not a proper behavior for the investor, since the mentor's account causes the investor to make inappropriate decisions. $23 \%$ of respondents are incapacitated, such respondents are afraid to take decisive action because they are not sure that the decision may not be optimal. If the change is already done and the worst case happens, then the respondent (after the event) is disappointed with his decision, because the investor knew that this should have happened. Also, these investors feel a stronger impulse to avoid losses than earn a profit. 


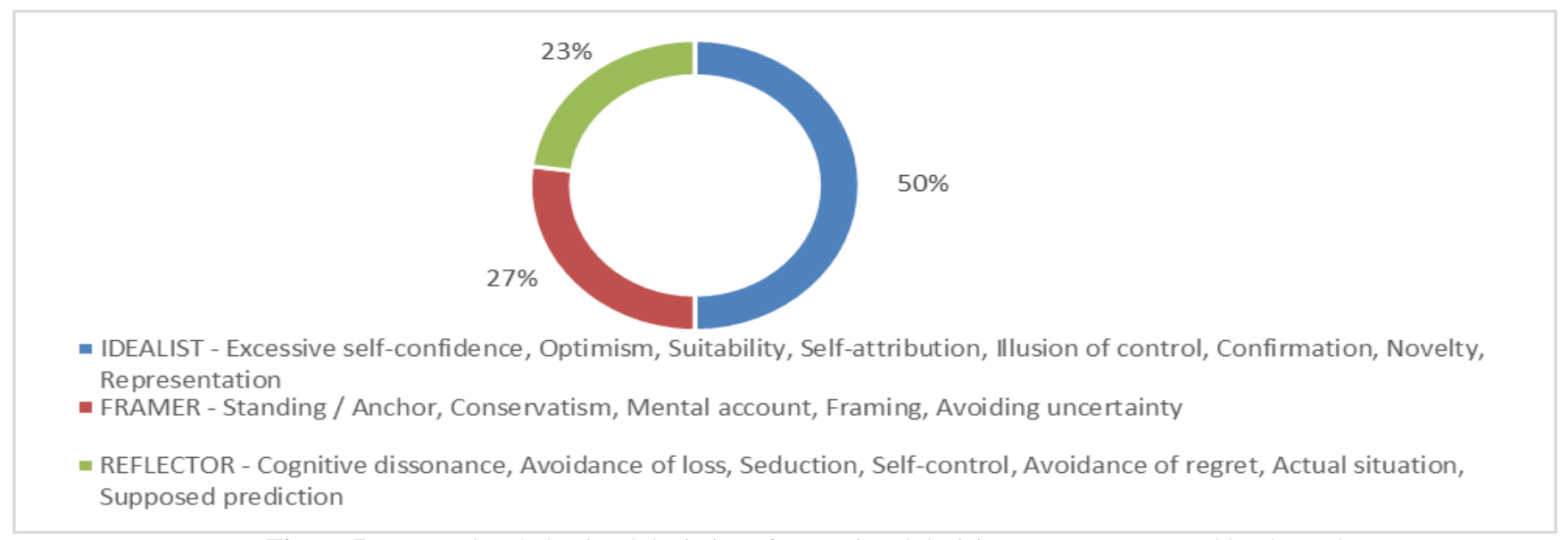

Figure 7. Respondent behavioral deviations from rational decisions. (Source: created by the author)

Summarizing the data of the research carried out, it is evident that the majority of respondents are distributed in the type of idealist-framer/integrator-realist. Only $17 \%$ of respondents are characterized by all possible behavioral deviations that are typical for the idealist-framer-reflector type. However, only $4 \%$ of respondents do not show any behavioral deviations. Based on the results of this research, respondents mostly have only one type of behavioral deviations. To say that respondents have become less rational after the financial crisis is nor right, their behavioral deviations are still affected by behavioral deviations, and in particular by avoiding losses.

Investors who do not show any deviant behavior make only $4.04 \%$. Rational investors with some irrational impurities are about $41.41 \%$. However, according to the survey results, irrational investors account for more than rational (54.54\% of irrational respondents and $45.45 \%$ of rational and partially rational respondents). The majority of investors with certain behavioral deviations are characterized by idealistic behavioral deviations. They are characterized by excessive self-confidence, self-attribution, illusion of control, and optimism. Regular respondents have characteristics of the framers and reflector behavior - conservatism, mental accounting, anchoring, loss avoidance, regret, and supposed prediction of the situation.

The results of the research are compared with the results of a study carried out by E. Bikas, A. Kavaliauskas (2010) and the research carried out by E. Bikas, D. Jurevičienė, L. Novickytè, G. Keliuonytė-Steniulienè and P. Dubinskas (2013). These authors conducted surveys of investors in 2010 and 2013, and outperformed investor types using the Pompian model.

During the research, it turned out that in 2010, $13 \%$ of respondents noted a completely rational behavior (pragmatic-integrator-realist), while the author's study revealed that the percentage of completely rational investors dropped threefold, i.e. it make now only $4.04 \% .40 \%$ of the respondents were rational investors, who partially do not respond to emotions, demonstrate rational behavior with irrational behavioral impurities (pragmatic-integrator-reflector, pragmatic-framer-realist, idealist-integrator-realist). The same result was obtained in this empirical study. The 2010 survey found out that irrational investors with rational behavioral impurities made $39 \%$, and it turned out such type of investors make $37.37 \%$. Meanwhile, totally irrational investors in 2010 were only $8 \%$ of respondents, and during the research it turned out that there are $17.17 \%$ of respondents of such type. The results of both surveys show that men are more rational investors than women, who make emotional decisions and are more responsive.

In the 2010 empirical study, it turned out that the majority of respondents, even $77 \%$, have a type of framers behavioral deviations. They are conservative, they accumulate assets into mental accounts (this forces the investor 
The International Journal

ENTREPRENEURSHIP AND SUSTAINABILITY ISSUES

ISSN 2345-0282 (online) http://jssidoi.org/jesi/ 2018 Volume 6 Number 1 (September) http://doi.org/10.9770/jesi.2018.6.1(4)

to make inappropriate investment decisions), framing, avoiding uncertainty and anchoring. $35 \%$ of the respondents have idealist behavioral deviations. Meanwhile, in this study, it turned out that even $50 \%$ of respondents have behavioral deviations of idealist type. These respondents are more likely to trust themselves too much, assign merit to themselves, optimistically look at the situation, imagine that they control situation by 100 $\%$. More than a quarter of respondents noted the deviations of the framer's behavior, i.e. y $27.11 \%$ of respondents. $22.89 \%$ of respondents were characterized by avoidance of loss, regret avoidance, supposed prediction, in other words, reflector-type behavioral deviations.

Summarizing the results of both surveys, it can be seen that there were more rational investors in 2010, which were only partially characterized by behavioral deviations. Most of these rational investors were men, and women were more likely to have behavioral deviations. Respondents with behavioral deviations tended to be marked by deviations from the framer. The 2016 study found out that there are more irrational investors with behavioral deviations. The most common behavioral deviation among respondents was the type of idealist. They trust themselves too much, are optimistic and think that everything depends on them. Men were most rational investor types, and women were more irrational.

Comparing the survey results of 2013 with the results of the research carried out by E. Bikas, D. Jurevičienė, L. Novickytė, G. Keliuonytė-Steniulienè and P. Dubinskas in 2013, $14 \%$ of respondents were marked by a completely rational behavior (pragmatist-integrator-realist), revealed that while in the research of the author it indicated that the percentage of completely rational investors dropped threefold, that is, now only $4.04 \% .48 \%$ of the respondents were rational investors, who partially do not respond to emotions, demonstrate rational behavior with irrational behavioral impurities (pragmatic-integrator-reflective, pragmatic-framer-realist, idealist-integratorrealist). A similar result was obtained in this study, with $41.41 \%$ of this type of respondents identified.

The 2013 survey found out that irrational investors with rational behavior impurities were $36 \%$, and today they $37.37 \%$ indicated. Meanwhile, totally irrational investors in 2013 were only $2 \%$ of respondents, and during the research it turned out that there are even $17.17 \%$ of respondents, i.e. y almost 9 times higher than in 2013.

It is also estimated which type of investor dominates by gender. In 2013, the distribution of all types by gender was equal. The type of idealist - framer - reflector was distinct (the type with all possible behavioral deviations), which was noted only for the woman, and the idealist-integrator- reflector dominated by men. Types of women were pragmatic-framer/integrator-realistic. The results of the 2013 survey showed that women are more pragmatic and that men tend to be more idealistic. In the 2016 study, the gender outcomes were slightly different, men were more pragmatic and women were idealistic. The only exception is that only men were pragmatic-framer-realist type. The size of an entirely irrational investor type was marked by both women and men, but the number of female investors is higher than that of men. And during this study, it turned out that men are more rational investors than women.

Summarizing the results of the research, it can be seen that, as in 2013, there were more rational investors who, in most cases, only partially have behavioral deviations. Most of these rational investors were men, and women were more likely to have behavioral deviations. The 2016 study indicated that there are more irrational investors with behavioral deviations. Men were most marked by rational investor types, and women were more irrational.

The likely difference between the results of the research (the investors were more rational during the crisis period, and now investors are more likely to have different behavioral deviations) was affected by the fact that in 2010 and 2013 investors were somewhat more cautious because during the crisis period it was necessary to cautiously carry out financial investments in order to minimize the risk of losses. Meanwhile, at the moment, respondents have become more irrational and make decisions less thoughtful and impulsive. This may have an effect on the 
The International Journal

ENTREPRENEURSHIP AND SUSTAINABILITY ISSUES

ISSN 2345-0282 (online) http://jssidoi.org/jesi/ 2018 Volume 6 Number 1 (September) http://doi.org/10.9770/jesi.2018.6.1(4)

recovery of the economy, the Bank of Lithuania predicted that in 2016, Real GDP of Lithuania will increase by $2.6 \%$ - significantly more than in 2015 (1.6\%). In the longer term, namely in 2017, economic development should accelerate further, as it would boost by the growing economic development of many regions of the world. Also, in recent years, wages grew by $5 \%$ a year, and this year, with further declining unemployment and a rise in the minimum wage, its growth rate should increase even more.

\section{Conclusions}

Analyzing the results of the survey, it is seen that the majority of respondents are characterized by an idealistintegrator/framer-realist. It can be argued that these are the dominant features of a typical Lithuanian investor's. Their distribution by gender is almost the same. People of this type are mostly characterized by excessive selfconfidence, illusion of control, newness, representation, optimism, self-affiliation. Sometimes they demonstrate standing/anchor, conservatism, mental accounts, avoiding uncertainty, framing. However, they have a realistic view of the situation.

A type that is characterized by all possible behavioral deviations is an idealist-framer-reflector, representing $17.17 \%$ of all respondents and to a large extent women are of this type of investor. A type that does not show any behavioral deviations is pragmatist-integrator-realist; this type of investor makes only $4.04 \%$ of respondents.

The majority of investors with certain behavioral deviations are characterized by idealist behavioral deviations. Regular respondents are characterized by the characteristics of the framer and reflector behavior.

In 2010, there were more rational investors, who partially have behavioral deviations. The 2016 study found out that there are more irrational investors with behavioral deviations. In 2010, respondents with behavioral deviations tended to be inferior to the framer, and in 2016 the most common behavioral deviation among respondents was observed in the idealist type.

Comparing the results of the survey of 2013 and 2016, it has been observed that men are more rational investors than women. In 2013, there were more rational investors, which are only partially characterized by behavioral deviations. The 2016 study indicated that there are more irrational investors with behavioral deviations. This figure has increased by as much as 9 times in three years, in 2013 the total number of irrational investors was only $2 \%$, and in 2016 the figure rose to $17.17 \%$.

\section{References}

Aleknevičienė V. 2004. Imonès finansu valdymas [Corporate finance management]. Akademija.

Bikas, E.; Kavaliauskas, A. 2010. Lietuvos investuotojų elgena finansų krizès metu [Behaviour of Lithuanian investor during financial crisis], Verslas:teorija ir praktika 11(4): 370-380. 0001:J.04 2010 1367178995042/DS.002.0.01.ARTIC

Bikas, E.; Jurevičienè, D.; Novickytè, L.; Keliuonytè-Steniuliene, G.; Dubinskas, P. 2013. Neprofesionaliu investuotojų elgsena finansu rinkose [Behaviour nonprofessional investors in financial markets]. Kaunas: Technologija,

Bodie, Z.; Kane, A.; Marcus, A. 2007. Investments. New York: McGraw-Hill.

Fromet, H. 2001. Behavioural finance - theory and practical application, Business Economics 7(1): 50-69. 
The International Journal

ENTREPRENEURSHIP AND SUSTAINABILITY ISSUES

ISSN 2345-0282 (online) http://jssidoi.org/jesi/ 2018 Volume 6 Number 1 (September) http://doi.org/10.9770/jesi.2018.6.1(4)

Fuller, R. J. 2000. Behavioural finance and the sources of alpha. Retrieved from: http://www.fullerthaler.com/downloads/bfsoa.pdf

Ggoldberg, J.; Von Nitzsch R. 1999. Behavioural Finance, John Wiley\&Sons.

Gitman, L.J. 2008. Study Guide for Principles of Managerial Finance by Lawrence J. Gitman (2008-02-11) https://www.amazon.co.uk/Principles-Managerial-Finance-Lawrence-2008-02-11/dp/B01A68SSJU

Jelnova, C. V. 2013. Analysis of the Practice of Decision-Making in the Field of Investment Policy, Contemporary Economic Issues 4.. http://doi.org/10.24194/41302

Jordan, B.; Miller, T. 2008. Fundamentals of investments. McGraw-Hill.

Ohotina, A.; Lavrinenko, O.; Ignatjeva, S.; Lonska, J. 2018. Socio-economic security as a determinant of regional differences in the investment climate in the region, Journal of Security and Sustainability Issues 7(3): 427-438. https://doi.org/10.9770/jssi.2018.7.3(5)

Tversky, A.; Kahneman, D. 1981.The Framing of Decisions and the Psychology of Choice, Science Vol. 211, 30 https://www.uzh.ch/cmsssl/suz/dam/jcr:ffffffff-fad3-547b-ffff-ffffe54d58af/10.18_kahneman_tversky_81.pdf

Kunitsyna, N.; Britchenko, I.; Kunitsyn, I. 2018. Reputational risks, value of losses and financial sustainability of commercial banks, Entrepreneurship and Sustainability Issues 5(4): 943-955. http://doi.org/10.9770/jesi.2018.5.4(17)

Levy, H.; Post, T. 2005. Investment, Prentice Hall.

Lovric, M.; Kayman. U.; Spronk, J. 2008. A conceptual model of invest behavior. Retrieved from: http://www.cse.salford.ac.uk/cogsys/CogSys-Lovric-update\%20(2).pdf

Mentel, G.; Szetela, B.; Tvaronavičienė, M. 2016. Qualifications of managers vs. effectiveness of investment funds in Poland, Economics \& Sociology 9(2): 126-137. http://dx.doi.org/dx.doi.org/10.14254/2071-789X.2016/9-2/8

Michailova, J.; Mačiulis, A.; Tvaronavičienė, M.. 2017. Overconfidence, risk aversion and individual financial decisions in experimental asset markets, Economic research $=$ Ekonomska istraživanja 30(1): 1119-1131. http://dx.doi.org/10.1080/1331677X.2017.1311234

Ozerchuk, O. V. 2014. Analysis of the Impact of Public Crediting Policy on the Investment Activity in Ukraine, Contemporary Economic Issues 1. http://doi.org/10.24194/11410

Pompian, M. M. 2010. Behavioral finance and wealth management. Canada: John Wiley \& Sonsh.

Ritter, J.R. 2002. Behavioural finance. Retrieved from: http://bear.cba.ufl.edu/ritter

Robinson, J. 1999. https://followthemoney.com/about/

Shefrin, H. 2001. Behavioural corporate finance, Journal of applied corporate finance. No. 14(3).

Sinem, P.; Bora, A.; Tvaronavičienè, M. 2017. Clustering in key G-7 stock market indices: an innovative approach, Marketing and Management of Innovations, 1: 300-310. http://dx.doi.org/10.21272/mmi.2017.1-27

Thaler, R.; Frame,s H.; Kahneman, D.; Tversky, A. 2000. Mental Accounting Matters, in Choices, Values. New York: Cambridge University Press. 
The International Journal

ENTREPRENEURSHIP AND SUSTAINABILITY ISSUES

ISSN 2345-0282 (online) http://jssidoi.org/jesi/

2018 Volume 6 Number 1 (September)

http://doi.org/10.9770/jesi.2018.6.1(4)

Egidijus BIKAS is the Associated Professor of Finance, Vilniaus University. Research interests: behavioral finance, investment, portfolio management, taxation, public finance.

ORCID ID: orcid.org/0000-0002-9667-3730

Vitalija SAPONAITE is the master of finance, Vilniaus University. Research interests: behavioral finance, investment, portfolio management.

ORCID ID: orcid.org/0000-0002-5398-4862

Register for an ORCID ID:

https://orcid.org/register

Copyright (C) 2018 by author(s) and VsI Entrepreneurship and Sustainability Center

This work is licensed under the Creative Commons Attribution International License (CC BY).

http://creativecommons.org/licenses/by/4.0/

cC) (†) Open Access 